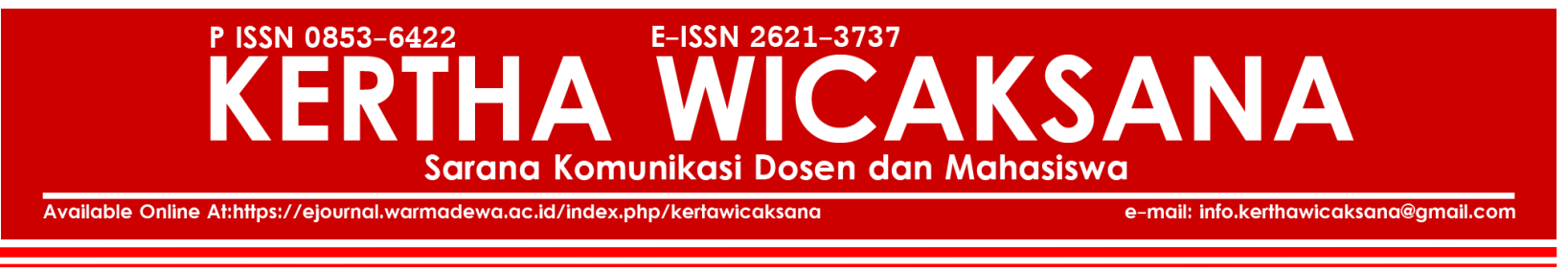

\title{
Implikasi Yuridis Perkawinan Campuran Terhadap Pewarisan Tanah Bagi Anak
}

\author{
Putu Devi Yustisia Utami \\ Fakultas Hukum, Universitas Udayana, Denpasar, Bali-Indonesia \\ deviyustisia27@gmail.com
}

\begin{abstract}
Published: 30/01/2021
How To Cite:

Utami, P. D. Y. (2021). Implikasi Yuridis Perkawinan Campuran Terhadap Pewarisan Tanah Bagi Anak. KERTHA WICAKSANA: Sarana Komunikasi Dosen dan Mahasiswa. 15(1). Pp 80-89. https:// doi.org/10.22225/kw.15.1.1843.80-89

Abstrak

WNI dan WNA yang melangsungkan perkawinan di Indonesia dapat menghadapi suatu permasalahan mengenai status personal anak yang dilahirkan dan sistem pewarisan hak atas tanah bagi anak, mengingat kedua orang tuanya tunduk pada yurisdiksi hukum yang berbeda. Penelitian ini bertujuan untuk mengetahui implikasi yuridis perkawinan campuran terhadap kewarganegaraan anak beserta sistem pewarisan hak atas tanahnya. Jenis penelitian hukum normatif dipergunakan dalam penulisan karya ilmiah ini. Adapun kesimpulan yang ditarik pertama, implikasi yuridis perkawinan campuran terhadap kewarganegaraan anak adalah sang anak menjadi menjadi memiliki dwi kewarganegaraan terbatas, kedua, Hukum Agraria menentukan bahwa anak yang memiliki dwi kewarganegaraan hanya dapat mewarisi tanah yang berupa hak pakai (HP) dan tidak diperbolehkan mewarisi tanah hak milik (HM), hak guna usaha (HGU) maupun hak guna bangunan (HGB).
\end{abstract}

Kata Kunci: Anak; Waris; Hak Atas Tanah; Perkawinan Campuran

\begin{abstract}
Indonesian citizens and foreigner who carry out marriages in Indonesia can face any problems regarding the personal status of the child and the inheritance system of the land rights, by considering both of their parents are subject to different legal jurisdictions. This study aims to determine the juridical implications of mixed marriages on the citizenship of the children and the inheritance system of the land rights. Normative legal research is used in this paper. The conclusions are, first, the juridical implications of mixed marriages to the citizenship of the children are the children has limited dual citizenship, second, according with Agrarian Law, children who have dual citizenship can only inherit land use rights and can't inherit ownership rights, bussiness use right and building right.
\end{abstract}

Keywords: Children; Inheritance; Property Rights; Mixed Marriages

\section{PENDAHULUAN}

Zoon politicon merupakan istilah terkenal dari Aristoteles yang menyatakan bahwa manusia sebagai seorang individu tidaklah dapat hidup sendiri, melainkan harus berhubungan dengan manusia yang lain. Manusia tidak hanya melakukan hubungan relasi satu sama lain tetapi juga melakukan hubungan dalam membentuk suatu keluarga. Pasal 28 B UUD 1945 menentukan bahwa seluruh manusia mempunyai suatu hak untuk membentuk keluarga.

Manusia melakukan perkawinan dalam rangka membentuk suatu keluarga dan mencapai tujuan untuk memperoleh keturunan. Ketentuan perkawinan diatur di UU No.1-1974 tentang Perkawinan (pada tulisan ini disebut UU Perkawinan) juncto UU No. 16-2019 tentang Perubahan UU Perkawinan (pada tulisan ini disebut UU Perkawinan Perubahan). Definisi perkawinan diatur berdasarkan ketentuan UU Perkawinan pada pasal 1 yaitu suatu ikatan diantara seorang pria dan wanita secara lahir dan bathin sebagai pasangan suami isteri yang bertujuan membentuk rumah tangga yang dipenuhi kebahagiaan dan langgeng yang 
berlandaskan Ketuhanan Yang Maha Esa.

Pada jaman serba modern seperti sekarang ini, meningkatnya pemanfaatan IT dan komunikasi yang begitu pesat memberikan berbagai kemudahan bagi manusia. Manusia dapat melakukan komunikasi dengan manusia lainnya tanpa perlu khawatir akan adanya batasan jarak dan waktu. Kini masyarakat dapat berkomunikasi satu sama lain tanpa terhambat jarak melalui media internet. Selain itu, dengan adanya perkembangan teknologi informasi melalui internet dan sosial media ternyata berdampak terhadap adanya kemajuan di bidang ekonomi, bisnis, pendidikan, budaya dan pariwisata di Indonesia. Hal ini tentu saja menyebabkan adanya perubahan ke arah yang lebih positif dimana tidak hanya dapat meningkatkan minat para wisatawan asing untuk travelling ke Indonesia tetapi juga meningkatkan minat tenaga kerja asing (TKA) untuk merambah lapangan pekerjaan di Indonesia. Tidak hanya itu saja, ternyata globalisasi juga memiliki pengaruh yang sangat signifikan terhadap adanya fenomena perkawinan campuran di Indonesia.

Perkawinan antara orang yang berkewarganegaraan asing (WNA) dengan orang asli Indonesia kini cukup sering terjadi di Indonesia. Perkawinan beda kewarganegaraan ini lebih familiar diistilahkan sebagai perkawinan campuran. Perkawinan campuran yang masuk kedalam ranah Hukum Perdata Internasional dipandang menimbulkan begitu banyak implikasi yuridis. Dimana pada perkawinan campuran baik pihak suami dan pihak istri masing- masing tunduk kepada yurisdiksi hukum yang berbeda. Hal ini tentu sangat mempengaruhi kedudukan dan status personalitas dari pihak suami dan pihak istri. Oleh karena adanya perbedaan status personalitas suami dan istri, maka hal ini tentu juga akan berimbas pada kedudukan atau status hukum dari sang anak yang dilahirkan dari pasangan atau orang tua yang berbeda kewarganegaraan. Selain mengenai status kedudukan anak, dalam perkawinan campuran seringkali muncul persoalan mengenai pewarisan, hal ini akan terjadi ketika salah satu orang tua meninggal dunia. Apabila pasangan yang melakukan perkawinan campuran ternyata memiliki harta peninggalan, maka yang akan menjadi persoalan adalah mengenai sistem pewarisan bagi anak yang dilahirkan dalam perkawinan beda kewarganegaraan tersebut.

Sangat menarik untuk dilakukan suatu penelitian mengenai "Implikasi Yuridis

Perkawinan Campuran Terhadap Pewarisan Tanah Bagi Anak". Penulis menemukan permasalahan yang menarik untuk dikaji yaitu pertama (1), Bagaimana implikasi yuridis suatu perkawinan campuran atas kewarganegaraan anak yang dilahirkan? kedua (2), Apakah anak yang lahir dalam perkawinan campuran dapat mewarisi tanah yang berlokasi di Indonesia?. Penelitian ini dilakukan dengan tujuan untuk memperoleh pengetahuan mengenai implikasi yuridis perkawinan campuran atas kewarganegaraan anak serta memperoleh pengetahuan mengenai pewarisan hak atas tanah bagi anak yang dilahirkan dari perkawinan beda kewarganegaraan (perkawinan campuran).

\section{METODE}

Jenis penelitian yuridis normatif dipergunakan dalam penelitian ini. Adapun jenis pendekatan yang penulis pergunakan dalam menulis karya tulis ini adalah conceptual approach dan statute approach. Dilakukan pengumpulan bahan hukum primer dengan mencari aturan dari hierarki tertinggi sampai dengan aturan yang menduduki hierarki terendah (Diantha, 2016) yang berkaitan dengan permasalahan perkawinan campuran. Dilakukan pencarian data pada jurnal-jurnal dan buku-buku terkait sebagai bahan hukum sekunder dan tertier, kemudian bahan hukum dianalisis dan disajikan dengan teknik deskriptif.

\section{HASIL DAN PEMBAHASAN}

\section{Keabsahan Perkawinan Campuran}

Sebelum membahas mengenai implikasi kewarganegaraan anak, terlebih dahulu akan dibahas mengenai perkawinan campuran itu sendiri. Melalui perkawinan seseorang dapat melegalkan hubungan hukum antara seorang perempuan dan seorang laki-laki guna melalui kehidupan berumah tangga guna memperoleh keturunan.

Profesor Subekti memberikan pandangannya mengenai definisi dari perkawinan, yaitu suatu pertalian atau ikatan yang legal dan dalam waktu yang lama yang dilakukan oleh seorang laki- laki dan seorang perempuan" (Subekti, 2003). Beberapa sarjana seperti Wiarda, Asser, Petit, Scholten, Pitlo, dan Melis juga memberikan pengertian mengenai apa itu perkawinan, bahwa perkawinan diartikan sebagai adanya suatu persatuan diantara wanita dan pria yang memperoleh pengesahan dan pengakuan dari 
negara dengan tujuan melangsungkan kehidupan bersama atau persekutuan yang kekal" (Salim, 2011).

Hukum positif Indonesia sendiri telah mengatur ketentuan mengenai Perkawinan pada UU No.1-1974 juncto UU No.16-2019 tentang Perubahan atas UU Perkawinan. Oleh karena UU Perkawinan perubahan terbaru hanya mengatur mengenai ketentuan usia minimal para mempelai dalam melangsungkan perkawinan dan dispensasi apabila terjadi penyimpangan mengenai umur minimal tersebut, maka untuk ketentuan mengenai perkawinan selain yang telah diubah oleh UU Perkawinan Perubahan, termasuk ketentuan mengenai perkawinan campuran masih tetap tunduk kepada ketentuan UU Perkawinan No.1-1974.

Suatu perkawinan baru dikatakan sah jika calon mempelai telah melangsungkan perkawinan berdasarkan hukum agama yang dianut dan kepercayaan dari para mempelai yang kemudian dilakukan pencatatan sesuai dengan peraturan perundang-undangan. Untuk dapat melangsungkan perkawinan harus memenuhi syarat berdasarkan ketentuan pasal 6 UU Perkawinan No.1-1974 juncto pasal 7 UU Perkawinan Perubahan No. 16-2019 yaitu:

- Dibutuhkan adanya persetujuan dari kedua belah pihak calon mempelai atas terlaksananya suatu perkawinan.

- Dibutuhkan persetujuan dari kedua orang tua, apabila calon mempelai berada dibawah usia 21 tahun. Jika baik ayah maupun ibunya telah meninggal dunia maka haruslah diperoleh persetujuan dari wali, namun jika hanya salah seorang dari orang tuanya yang meninggal dunia, maka mempelai harus memperoleh persetujuan dari salah satu orang tua yang masih hidup.

- Seorang perempuan dan laki- laki hanya bisa melangsungkan perkawinan jika telah berusia 19 tahun. Diperlukan adanya ijin pengecualian dari Pengadilan atau pejabat lainnya jika terjadi penyimpangan atas hal ini.

Sama halnya dengan ketentuan dalam melaksanakan suatu perkawinan biasa antar warga negara Indonesia, ketentuan perkawinan antara orang asing dan WNI juga tunduk pada ketentuan UU Perkawinan tepatnya pasal $57 \mathrm{~s} / \mathrm{d}$ pasal 62. Berdasarkan ketentuan pasal $57 \mathrm{UU}$ Perkawinan, perkawinan yang dilangsungkan di
Indonesia antara dua orang yang memiliki kewarganegaraan yang berbeda dimana yang satu memiliki kewarganegaraan asing dan yang lainnya merupakan warga negara Indonesia, sehingga hal ini menyebabkan keduanya tunduk kepada hukum yang berbeda adalah merupakan pengertian dari perkawinan campuran.

Atas dasar pengaturan perkawinan campuran di pasal 57 UU Perkawinan, adapun unsur-unsur penting perkawinan campuran atau perkawinan beda kewarganegaraan yakni:

- Dilakukan di Negara Indonesia oleh perempuan dan laki- laki serta kedua mempelai tunduk pada yurisdiksi hukum yang berbeda;

- Para pihak memiliki perbedaan kewarganegaraan;

- Salah seorang calon mempelai haruslah seorang WNI (Rampay, 2015).

Dengan adanya unsur asing pada perkawinan campuran, maka perkawinan campuran berada di dalam ranah atau lapangan Hukum Perdata Internasional (HPI). Hal ini karena disebabkan adanya foreign element yang dalam hal ini adalah perbedaan kewarganegaraan antara keduabelah pihak. Adanya unsur kewarganegaraan asing inilah yang kemudian melahirkan suatu hubungan yang bersifat Internasional. Adanya hubungan perkawinan antara perempuan dan laki-laki yang menundukkan diri kepada hukum yang berbeda tentunya dikemudian hari dapat menimbulkan suatu implikasi yuridis pada lapangan hukum keluarga dalam Hukum Perdata Internasional.

Ketika sepasang calon suami istri yang berbeda kewarganegaraan akan melangsungkan perkawinan timbullah suatu pertanyaan, hukum manakah yang berlaku bagi sahnya perkawinan calon mempelai tersebut. Apakah hukum perkawinan di negara si mempelai pria atau hukum perkawinan di negara mempelai wanita. Untuk mengetahui hal tersebut haruslah kita kaji dari sisi Hukum Perdata Internasional. Terlebih dahulu harus kita lakukan identifikasi terhadap titik- titik taut dalam perkara HPI itu sendiri. Menurut Bayu Seto, titik taut adalah fakta- fakta yang dapat kita temukan dalam permasalahan hukum perdata internasional yang menunjukkan adanya hubungan atau pertautan antara permasalahan hukum tersebut dengan suatu negara tertentu. Hal ini menyebabkan terciptanya 
suatu relevansi antara permasalahan hukum tersebut dengan hukum yang berlaku di suatu negara tertentu (Seto, 2001).

Dalam perkawinan campuran, dapat kita lihat bahwa titik taut primernya adalah mengenai adanya perbedaan kewarganegaraan si pria dan si wanita, kemudian untuk mengetahui hukum yang berlaku terhadap permasalahan perkawinan campuran ini haruslah dilihat melalui titik taut sekundernya. Dalam HPI dikenal adanya asas dalam bidang hukum perkawinan yang biasa disebut dengan asas "Lex Loci Celebrationis" yang artinya dalam suatu perkawinan hukum yang berlaku tergantung pada tempat perkawinan itu diresmikan atau dilangsungkan (celebrations) (Khairandy, 2007).

UU Perkawinan memberikan batasan bahwa tempat dilangsungkannya perkawinan sebagaimana yang dimaksudkan dalam UU ini adalah perkawinan yang dilangsungkan di negara Indonesia. Oleh karena dilangsungkan di Indonesia maka berdasarkan asas lex loci celebrationis maka hukum Indonesialah yang dijadikan sebagai dasar hukum dalam perkawinan campuran itu. Dalam pasal 59 ayat (2) UU Perkawinan menentukan bahwa perkawinan campuran yang dilaksanakan oleh para pihak di Indonesia dilangsungkan berdasarkan UU No.11974. Berarti bahwa keabsahan suatu perkawinan campuran yang dilaksanakan di Indonesia ditentukan oleh dipenuhi atau tidaknya ketentuan hukum perkawinan yang diatur dalam UU Perkawinan.

Keabsahan suatu perkawinan campuran menurut hukum di Indonesia ditentukan oleh ketentuan pasal 2 UU Perkawinan yaitu pelaksanaannya wajib berdasarkan hukum agama yang dianut oleh masing-masing mempelai serta wajib dilakukan pencatatan berdasarkan peraturan perundang- undangan Indonesia. Perkawinan campuran yang dilaksanakan di Indonesia hanya dapat dilangsungkan apabila syarat dan ketentuan perkawinan yang berlaku bagi para pihak baik itu pihak pria dan pihak wanita telah dipenuhi.

Bagi calon mempelai yang berkewarganegaraan Indonesia, wajib memenuhi persyaratan perkawinan sebagaimana ketentuan Bab II UU No.1-1974 tentang syarat perkawinan, yaitu pada pasal 6-12. Sedangkan bagi calon mempelai yang berkewarganegaraan asing, maka wajib memenuhi persyaratan perkawinan sesuai dengan hukum yang berlaku di negaranya sendiri. Untuk mengetahui bahwa syarat perkawinan bagi masing-masing calon mempelai telah terpenuhi maka haruslah dibuktikan dengan diberikannya surat keterangan oleh pejabat berwenang yang menerangkan bahwa persyaratan perkawinan yang ditentukan oleh hukum masing- masing telah dipenuhi oleh para pihak. Akan tetapi jika pejabat yang berwenang melakukan penolakan untuk memberikan surat keterangan, maka dapat dimohonkan keputusan Pengadilan mengenai alasan penolakan pemberian surat keterangan tersebut. Apabila Pengadilan menyatakan bahwa penolakan tersebut tdak beralasan, maka keputusan pengadilan dijadikan pengganti surat keterangan pemenuhan syarat perkawinan campuran. Surat keterangan/ keputusan pengganti keterangan pada perkawinan campuran hanya memiliki masa berlaku selama 6 (enam bulan) sejak diterbitkan oleh pejabat yang berwenang.

Keabsahan perkawinan campuran di Indonesia ditentukan oleh telah terpenuhi atau tidaknya syarat-syarat sebagaimana tercantum dalam pasal 59 ayat (2) UU Perkawinan. Jika suatu perkawinan campuran dilaksanakan dengan sah, maka akan menjadikan status sang anak yang dilahirkan juga sah menurut hukum.

\section{Implikasi Hukum Perkawinan Campuran Bagi Kewarganegaraan Anak.}

Dalam suatu perkawinan, tentu saja hadirnya seorang anak sebagai penerus keluarga merupakan harapan setiap pasangan suami isteri. UU Perkawinan sendiri tidak memberikan definisi yang jelas mengenai pengertian anak. Namun dalam Burgerlijk Wetboek (selanjutnya disebut BW), sebagaimana dicantumkan pada ketentuan pasal $330 \mathrm{BW}$ anak dapat dipadankan dengan pengertian orang yang belum dewasa, yakni orang-orang usianya belum genap 21 (dua puluh satu) tahun serta tidak pernah melakukan perkawinan kawin sebelumnya.

Definisi anak juga telah tersurat di ketentuan pasal 1 angka 1 UU Perlindungan Anak No. 352014 tentang Perubahan UU No. 23-2002, yaitu orang usianya belum genap mencapai 18 (delapan belas) tahun, yang termasuk juga anak yang belum dilahirkan dan masih dalam kandungan. Berdasarkan ketentuan pasal 1 Convention On The Rights of the Child pengertian anak yaitu :

"Every human being below the age of eighteen years unless under the law applicable to the child, majority is attained earlier".

(terjemahan bebas oleh penulis : anak ialah setiap orang yang umumnya berusia dibawah 18 
(delapan belas) tahun kecuali undang- undang menentukan bahwa kedewasaan dapat dicapai lebih awal) (Child, 1989).

Walaupun UU Perkawinan sendiri tidak memberikan definisi yang tegas mengenai pengertian anak, akan tetapi Pasal 6 UU Perkawinan menentukan bahwa diwajibkan adanya ijin dari orang tua bagi orang- orang yang akan melaksanakan perkawinan namun usianya belum menginjak usia 21 (dua puluh satu). Dari ketentuan pasal 6 UU Perkawinan dapat diartikan bahwa batasan seseorang dapat dikatakan sebagai seseorang yang belum dewasa (anak) menurut UU Perkawinan adalah seseorang yang berumur dibawah 21 (dua puluh satu) tahun atau belum pernah melangsungkan perkawinan.

Berdasarkan ketentuan pasal 42 UU Perkawinan disebutkan "Anak sah adalah anak yang dilahirkan dalam perkawinan yang sah", hal ini dikuatkan pula dengan pendapat Profesor Subekti bahwa seorang anak akan menjadi anak yang sah apabila ia lahir dari seorang ibu dan ayah yang melakukan perkawinan yang sah. (Subekti, 2003). Begitupula halnya dengan seorang anak yang lahir dari suatu perkawinan campuran di Indonesia, anak tersebut akan menjadi anak sah berdasarkan hukum di Indonesia apabila kedua orang tuanya yang berbeda kewarganegaraan telah memenuhi legalitas dan syarat dalam melangsungkan perkawinan di Indonesia.

Adanya perbedaan kewarganegaraan pada perkawinan campuran menyebabkan pihak suami dan istri akan tunduk kepada hukum yang berbeda. Dengan tunduknya pasangan suami istri pada hukum yang berbeda, maka akan menimbulkan suatu pertanyaan mengenai status personalitas atau kedudukan hukum bagi anak yang dilahirkan serta kepada yurisdiksi negara manakah anak tersebut akan tunduk. Status personal diartikan sebagai peraturan hukum yang menyangkut kaidah hukum yang berlaku terhadap seseorang kemanapun orang itu pergi dan dimanapun orang itu berada (Arliman S, 2017).

Pasal 62 UU No.1-1974 menentukan bahwa kedudukan hukum seorang anak yang dilahirkan oleh seorang ibu yang melakukan perkawinan campuran ditentukan sesuai dengan pasal 59 ayat (1) UU No.1-1974, dimana kewarganegaraan yang diperoleh oleh sang anak yang dilahirkan oleh ibu yang melakukan perkawinan campuran akan menentukan hukum yang berlaku bagi anak tersebut. Mengenai implikasi yuridis perkawinan campuran terhadap status kewarganegaraan anak, dapat kita tinjau dari sisi peraturan hukum di bidang kewarganegaraan.

Melihat ketentuan pasal 13 UU No.62-1958 tentang Kewarganegaraan (dalam tulisan ini disebut UU Kewarganegaraan lama), bahwa status kewarganegaraan seorang anak yang sah akan mengikuti status kewarganegaraan ayahnya. Apabila sang ayah berkewarganegaraan Indonesia, maka anak tersebut akan memperoleh kewarganegaraan Indonesia, begitupula sebaliknya apabila ayahnya adalah seorang WNA maka anak tersebut akan menjadi berkewarganegaraan asing. Kewarganegaraan Indonesia dari sang Ibu hanya akan diperoleh oleh seorang anak apabila anak yang bersangkutan tidak memiliki hubungan kekeluargaan dengan ayahnya. UU Kewarganegaraan lama dianggap diskriminatif karena tidak menjamin persamaan kedudukan antar warganegara serta tidak mampu menjamin adanya perlindungan hukum bagi perempuan pelaku perkawinan campuran dan anak- anak yang kemudian dilahirkan dari suatu perkawinan campuran. (Parwitasari, 2010)

Pada tahun 2006, pemerintah kemudian menerbitkan UU Kewarganegaraan RI No.122006 (dalam tulisan ini disebut UU Kewarganegaraan). Berdasarkan ketentuan pasal 4 huruf c, d, dan h UU Kewarganegaraan ini, yang dimaksud dengan warganegara Indonesia terkait dengan perkawinan antara WNI dan orang berkewarganegaraan asing yakni:

- Anak yang bersangkutan dilahirkan dari suatu perkawinan antara seorang ayah berkewarganegaraan Indonesia dengan ibunya yang berkewarganegaraan asing dan dilakukan secara sah;

- Anak yang bersangkutan dilahirkan dari suatu perkawinan antara seorang ayah dengan kewarganegaraan asing dengan seorang ibu berkewarganegaraan Indonesia yang dilakukan secara sah;

- Anak yang dilahirkan dari ibu warganegara asing tanpa perkawinan yang sah (diluar perkawinan), namun memperoleh pengakuan oleh ayahnya yang merupakan WNI, dimana pengakuan tersebut diberikan sebelum sang anak mencapai usia 18 (delapan belas) tahun atau si anak belum pernah kawin.

Ketentuan pasal 4 poin huruf c, d dan h pada 
UU Kewarganegaraan tentu saja memberikan harapan baru bagi para WNI pelaku perkawinan campuran di Indonesia, sebab dapat memberikan jaminan kejelasan atas status hukum anak yang dilahirkan. Dengan diakuinya anak dilahirkan dari perkawinan antara WNI dan orang asing sebagai anak yang juga memiliki kewarganegaraan Indonesia, maka berdasarkan UU Kewarganegaraan implikasi yuridis dari perkawinan campuran terhadap kewarganegaraan anak adalah anak tersebut menjadi memiliki dwi kewarganegaraan (kewarganegaraan ganda). Terhadap anak yang memiliki dwi kewarganegaraan maka akan berlaku ketentuan UU Kewarganegaraan pasal 6 ayat (1) yang menentukan bahwa apabila status Kewarganegaraan Indonesia bagi anak yang lahir dari orang tua sebagaimana Pasal 4 huruf c, huruf $\mathrm{d}$, huruf h, huruf 1, dan Pasal 5 menyebabkan anak menjadi mempunyai dwi kewarganegaraan, maka setelah anak mencapai usia 18 (delapan belas) tahun atau setelah anak tersebut kawin, maka anak dengan dwi kewarganegaraan itu haruslah menentukan pilihan atas salah satu kewarganegaraannya. Baik itu pilihan sebagai WNI atau bahkan memilih menjadi WNA.

Dari ketentuan pasal tersebut diatas, maka dapat penulis sampaikan bahwa implikasi yuridis perkawinan campuran bagi anak yang dilahirkan adalah anak tersebut dapat memperoleh hak untuk memiliki dwi kewarganegaraan yang bersifat terbatas. Anak tersebut akan memiliki kewarganegaraan Indonesia disamping juga memiliki kewarganegaraan asing dari ayah atau ibunya yang merupakan WNA. Penyebutan kata "terbatas" dipergunakan karena dwi kewarganegaraan yang dimiliki oleh anak tersebut hanya berlaku sampai dengan anak yang bersangkutan mencapai usia 18 (delapan belas) tahun atau sampai dengan anak berdwi kewarganegaraan tersebut telah melangsungkan perkawinan. Jika sang anak telah mencapai usia 18 tahun atau telah melangsungkan perkawinan maka anak tersebut harus menyatakan kewarganegaraan yang dipilihnya dan menyampaikannya kepada Pejabat yang berwenang dalam waktu maksimal 3 (tiga) tahun.

\section{Pendaftaran Anak yang Memiliki Dwi Kewarganegaraan di Indonesia}

Sebagai peraturan pelaksanaan dari UU Kewarganegaraan, pemerintah telah menerbitkan Peraturan Menteri Hukum\&HAM mengenai cara pendaftaran anak dwi kewarganegaraan (kewarganegaraan ganda) beserta permohonan fasilitas keimigrasian No.22 Tahun 2012 (Dalam tulisan ini disebut dengan Permenkumham No. 22 -2012). Pada pasal 2 ayat (1) Permenkumham No. 22-2012 menentukan bahwa anak yang memiliki dwi kewarganegaraan wajib dilakukan pendaftaran oleh orang tuanya atau oleh walinya.

Ini artinya bahwa, hak untuk memperoleh dwi kewarganegaraan tidak secara serta merta dapat dimiliki oleh anak yang lahir dari orang tua yang melakukan perkawinan campuran, melainkan harus dilakukan pendaftaran terlebih dahulu. Pendaftaran dwi kewarganegaraan bertujuan untuk memperoleh fasilitas keimigrasian berupa kartu bagi anak subjek dwi kewarganegaraan yang diberikan secara affidavit. Affidavit merupakan suatu keterangan tertulis keimigrasian yang memuat keterangan sebagai anak yang memiliki dwi kewarganegaraan terbatas yang disatukan dengan Paspor asing. Affidavit ini diperlukan dalam rangka penerbitan Paspor RI yang ditunjukan bagi anak-anak yang memiliki dwi kewarganegaraan terbatas (Kementerian Luar Negeri, 2019).

Berdasarkan PP No.22-2012, pendaftaran anak dengan dwi kewarganegaraan bisa dilakukan di wilayah Indonesia yaitu kepada Kepala Kantor Imigrasi dan bisa juga dilakukan di luar wilayah negara Indonesia. Pasal 3 PP No. 22-2012 menyatakan bahwa pendaftaran diluar wilayah negara Indonesia dimohonkan kepada Kepala Kedutaan Besar/Perwakilan Republik Indonesia dan Pejabat Imigrasi yang telah mendapat penunjukan oleh Menteri dengan daerah kerja yang mencakup tempat kediaman anak yang memiliki dwi kewarganegaraan tersebut. Paspor biasa diberikan kepada anak yang memiliki dwi kewarganegaraan dan belum melakukan penentuan kewarganegaraan dan berlaku sampai dengan sang anak yang memiliki kewarganegaraan ganda berusia 21 (dua puluh) satu tahun (Lihat PP No.22-2012).

\section{Pewarisan Tanah Bagi Anak yang dilahirkan pada Perkawinan Campuran}

Pada subbab sebelumnya penulis telah memaparkan bahwa orang-orang yang melakukan perkawinan campuran tentu saja tunduk kepada hukum yang berbeda. Berdasarkan UU Kewarganegaraan, orang yang melakukan perkawinan campuran akan melahirkan anak-anak dengan dwi kewarganegaraan. Disatu sisi, hal ini dapat melindungi status dan kedudukan hukum anak tersebut, akan tetapi di sisi lain dengan 
adanya dwi kewarganegaraan ini juga menimbulkan suatu permasalahan baru menyangkut hukum mana yang berlaku terhadap anak tersebut. Dwi kewarganegaraan pada anak juga menimbulkan suatu persoalan jika salah satu orang tuanya yang berkebangsaan WNI meninggal dunia dan mewariskan sejumlah harta pada saat sang anak belum dewasa. Terlebih lagi jika harta warisan yang ditinggalkan adalah berupa hak atas tanah di Indonesia. Sebelum membahas tentang pewarisan tanah bagi anak yang memiliki dwi kewarganegaraan, maka terlebih dahulu akan penulis bahas mengenai jenis - jenis hak atas tanah yang ada di negara Indonesia.

Berdasarkan Undang-undang Peraturan Dasar Pokok-Pokok Agraria UU No.5-1960 (dalam tulisan ini disebut dengan UUPA), pada pasal 16 ayat (1) adapun klasifikasi hak atas tanah ada 7 (tujuh) yaitu : hak milik (HM), hak guna bangunan (HGB), hak guna usaha (HGU), hak sewa, hak pakai (HP), hak memungut hasil hutan dan hak membuka tanah. Hak milik (HM), hak guna bangunan (HGB), hak guna usaha (HGU) serta hak pakai (HP) merupakan hak atas tanah yang dimiliki oleh masyarakat pada umumnya.

Pengaturan mengenai hak milik (HM) ada dalam ketentuan pasal 20-27 UUPA. Hak milik ialah hak seseorang untuk memiliki atau mempunyai suatu tanah, dimana hak tersebut adalah hak yang bersifat paling kuat, terpenuh dan dapat diturunkan kepada keturunan selanjutnya. Hanya Warga Negara Indonesialah yang dapat menjadi subyek dari HM, namun tidak menutup kemungkinan bahwa ada badan hukum yang dapat menjadi subyek dari HM sepanjang memperoleh keputusan penetapan dari Pemerintah. Hak atas tanah berikutnya yaitu, Hak Guna Usaha (HGU) ialah hak untuk untuk melaksanakan kegiatan usaha dibidang perikanan, pertanian dan peternakan dengan cara mengusahakan tanah yang berada dalam penguasaan Negara secara langsung dengan kurun waktu selambat-lambatnya sampai dengan 25 (dua puluh lima) tahun berdasarkan adanya penetapan dari Pemerintah. Pengaturan HGU berada dalam ketentuan pasal 28-34 UUPA. Adapun subjek yang dapat mempunyai HGU yaitu hanyalah WNI dan badan hukum yang berkedudukan di Indonesia dan pastinya haruslah didirikan berdasarkan hukum yang berlaku di Indonesia. Selanjutnya, Hak Guna Bangunan (HGB) diatur pada ketentuan pasal 38-40 UUPA. Merupakan hak yang diberikan oleh negara untuk mendirikan serta memiliki bangunan yang didirikan diatas tanah milik orang lain dengan batas waktu selama-lamanya sampai dengan 30 (tiga puluh) tahun, dan kemudian dapat dilakukan perpanjangan kembali selama jangka waktu 20 (dua puluh) tahun. Hanya WNI serta badan hukum yang berkedudukan di Indonesia dan didirikan berdasarkan hukum yang berlaku di Indonesialah yang mampu memperoleh hak untuk memiliki HGB. Jadi pada dasarnya, baik HM, HGB maupun HGU subjeknya adalah warga negara Indonesia serta badan-badan hukum yang didirikan berdasarkan hukum Indonesia serta bertempat kedudukan di Indonesia. (lihat UUPA)

Hak atas tanah selanjutnya ialah hak pakai (HP), pengaturannya dapat kita lihat di ketentuan pasal 41-43 UUPA. Berdasarkan UUPA, hak yang pemberiannya berasal dari suatu keputusan pejabat yang berwenang atau berasal dari perjanjian antara pihak penerima hak pakai dan pihak pemilik tanah (pemberi hak pakai), untuk menggunakan serta melakukan pungutan hasil suatu tanah yang berada dalam penguasaan negara maupun dari tanah milik orang lain disebut dengan Hak Pakai (lihat UUPA). Masyarakat pada prinsipnya, diberikan kebebasan bebas untuk memperjanjikan sesuatu dengan pihak manapun dan mengenai apapun (freedom of contract) sepanjang tetap patuh kepada ketentuan undang- undang, ketertiban dan kesusilaan. (Utami, 2019) (Utami, Kajian Yuridis Agunan Yang Diambil Alih (AYDA), 2019). Namun dalam pemberian hak pakai, dilarang untuk menjadikan perjanjian pengelolaan tanah dan perjanjian sewa menyewa sebagai dasar pengikatan antara pemberi dan penerima hak pakai karena telah ditentukan demikian oleh undang- undang. Berbeda halnya dengan HM, HGU, dan HGB, khusus untuk hak pakai (HP) selain dapat dimiliki oleh WNI dan badan-badan hukum Indonesia yang bertempat kedudukan di Indonesia, orang berkewarganegaraan asing yang bertempat kedudukan di negara Indonesia serta badan hukum asing yang memiliki kantor cabang di Indonesia juga dapat memiliki hak pakai.

Berkaitan dengan anak yang memiliki dwi kewarganegaraan, apabila dikemudian hari salah satu atau bahkan kedua orang tuanya meninggal dunia pada saat anak tersebut masih dibawah umur (usia dibawah 21 tahun). Kemudian orang tuanya meninggalkan harta warisan yang berupa tanah yang berlokasi di Indonesia, maka akan timbul persoalan mengenai dapatkah anak yang memiliki dwi kewarganegaraan tersebut 
memperoleh hak waris atas tanah peninggalan orang tuanya.

Peristiwa turun waris adalah salah satu peristiwa yang sangat erat dengan kehidupan manusia. Hukum waris ialah sekumpulan kaidah/ aturan hukum yang memberikan pengaturan tentang proses pengalihan harta peninggalan dari seorang pewaris ke (para) ahli waris atau orang yang ditunjuk karena meninggalnya si pewaris (Muhammad, 2000). Adanya pewaris dan ahli waris merupakan subjek dalam hukum waris. Pewaris ialah seorang yang meninggal, baik pria maupun wanita yang semasa hidupnya memiliki harta-harta kekayaan tertentu dan ketika meninggal dunia kemudian meninggalkan harta kekayaannya tersebut. Sedangkan orang yang kemudian menggantikan posisi/kedudukan si pewaris karena kematian si pewaris disebut dengan ahli waris (Dewantari \& Putrawan, 2018). Dalam hukum keperdataan, terdapat 2 (dua) cara untuk memdapatkan warisan, yaitu dengan cara abintestanto (berdasarkan ketentuan undangundang) atau dengan cara testamen (wasiat) (Rudito, 2015). Perolehan waris melalui testamen (wasiat) didasarkan pada akta Notarill. Akta wasiat adalah salah satu bentuk akta otentik. Dimana akta yang dibuat oleh seorang pejabat yang memiliki kewenangan untuk hal tersebut berdasarkan ketentuan pasal 1868 KUHPerdata disebut dengan akta otentik. (Utami, 2018)

Dalam hal WNI pelaku perkawinan campuran meninggal dunia dan meninggalkan harta warisan dalam bentuk hak atas tanah bagi anaknya yang memiliki dwi kewarganegaraan, maka perlu dilakukan analisis dari sisi hukum agraria Indonesia untuk mengetahui apakah sang anak dapat mewarisi tanah warisan tersebut.

Untuk mengetahui dapat tidaknya anak yang memiliki dwi kewarganegaraan mewarisi tanah di Indonesia, maka pertama- tama harus dilihat terlebih dahulu alas hak dari tanah yang menjadi harta warisan tersebut. Apabila alas hak tanah warisan tersebut adalah berupa hak pakai, maka tentu saja sang anak yang memiliki dwi kewarganegaraan dapat langsung mewarisi tanah warisan peninggalan orang tuanya sebagaimana ketentuan pasal 42 UUPA.

Namun dalam hal tanah warisan yang ditinggalkan tersebut adalah hak milik maka berlakulah aturan-aturan pada pasal 21 UUPA. Subjek yang dapat memiliki hak milik berdasarkan pengaturan pasal 21 UUPA adalah hanya warganegara Indonesia serta badan hukum yang memperoleh penetapan oleh Pemerintah. Pada UUPA juga telah ditegaskan bahwa orang asing yang mendapatkan hak milik karena selama perkawinannya tidak memiliki perjanjian mengenai pemisahan harta perkawinan atau karena memperoleh warisan tanpa wasiat, serta WNI yang medapatkan hak milik namun kehilangan kewarganegaraan Indonesianya maka wajib melakukan pelepasan perolehan hak milik tersebut dalam jangka waktu selambat-lambatnya 12 (duabelas) bulan. Jika melampaui batas waktu 12 (duabelas) 12 bulan namun tidak dilakukan pelepasan atas hak milik tersebut, maka hapuslah hak milik dan kemudian menjadi milik Negara (lihat ketentuan pasal 21 ayat (3) UUPA). Demikian pula dengan tanah warisan dalam bentuk hak guna usaha maupun hak guna bangunan tidak boleh dimiliki oleh orang asing sebagaimana ketentuan penjelasan pasal 30 dan 36 UUPA.

Ini rupanya juga berlaku bagi anak yang memiliki dwi kewarganegaraan, dimana disamping memiliki kewarganegaraan Indonesia anak yang bersangkutan juga memiliki kewarganegaraan asing. Dimilikinya kewarganegaraan Indonesia disamping kewarganegaraan asing oleh anak tersebut tidak menyebabkan anak yang bersangkutan dapat mewarisi tanah dengan alas hak milik, hak guna bangunan dan hak guna usaha di Indonesia. Ini disebabkan adanya asas kebangsaan yang menjadi dasar bagi UUPA. Jika hal ini ditinjau dari ketentuan ayat (4) pada pasal 21 UUPA ditentukan pula bahwa orang yang memiliki kewarganegaraan asing disamping kewarganegaraan Indonesianya maka akan berlaku ketentuan pada ayat (3). Apabila seorang anak yang memiliki dwi kewarganegaraan memperoleh warisan berupa tanah hak milik, maka anak tersebut harus melepaskan tanah hak milik yang diperolehnya karena pewarisan tersebut dalam jangka waktu selambat- lambatnya 12 (duabelas) bulan. Penjelasan pasal 30 dan 36 UUPA juga telah menegaskan bahwa orang yang berkewarganegaraan asing juga tidak boleh menjadi subjek dari HGU dan HGB, artinya anak yang mempunyai dwi kewarganegaraanpun tidak boleh memiliki HGU dan HGB.

Artinya bahwa seorang anak yang mempunyai dwi kewarganegaraan, walaupun ia juga ialah seorang WNI namun ia tidak dapat mewarisi tanah peninggalan dari orang tuanya yang berbentuk hak milik, HGB maupun HGU. Anak dengan dwi kewarganegaraan hanya 
dimungkinkan untuk mewarisi tanah dalam bentuk hak pakai (HP). Untuk dapat mewarisi tanah dalam bentuk hak milik, HGB maupun HGU di Indonesia, maka anak yang memiliki dwi kewarganegaraan tersebut harus memilih kewarganegaraan Indonesia sebagai kewarganegaraan satu- satunya atau mendowngrade hak milik, HGU dan HGB yang diwarisinya menjadi hak pakai (HP).

\section{SIMPULAN}

Setelah melakukan pembahasan sebagaimana paparan sebelumnya, penulis sampai pada kesimpulan akhir yakni :

Implikasi yuridis perkawinan campuran terhadap kewarganegaraan anak berdasarkan ketentuan pasal 4 huruf $\mathrm{c}, \mathrm{d}$, dan $\mathrm{h}$ UU Kewarganegaraan adalah anak menjadi memiliki dwi kewarganegaraan yang bersifat terbatas. Selain memiliki kewarganegaraan ayah atau ibunya yang berkewarganegaraan asing, maka anak tersebut juga memiliki kewarganegaraan Indonesia yang bersifat terbatas, dimana pada saat usia anak tersebut sudah mencapai usia 18 tahun atau pada saat anak tersebut sudah kawin, maka anak dengan dwi kewarganegaraan tersebut harus menentukan pilihan kewarganegaraannya.

Sebagaimana ketentuan pasal 21 ayat (3) dan (4) serta penjelasan pasal 30 dan 36 UUPA, anak yang lahir dalam perkawinan campuran dan memiliki dwi kewarganegaraan hanya dapat mewarisi tanah dalam bentuk hak pakai. Tanah dengan hak milik, HGB maupun HGU di Indonesia tidak dapat diwarisi oleh seorang anak yang mempunyai dwi kewarganegaraan.

\section{DAFTAR PUSTAKA}

Arliman, L. (2017). Perkawinan Antar Negara Di Indonesia Berdasarkan Hukum Perdata Internasional, Kertha Patrika, 39(03), 176-192. Retrieved from https://ojs.unud.ac.id/index.php/ kerthapatrika/article/view/32954

Child, C. T. (n.d.). Convention on the Rights of the Child. United Nation Human Rights. Retrieved September 17, 2019, from https:// www.ohchr.org/en/professionalinterest/pages/ crc.aspx. (diaskes pada tanggal 04 April 2020)

Kementerian Luar Negeri, O. (n.d.)., Kewarganegaraan Ganda Terbatas Untuk Anak. Kedutaan Besar Republik Indonesia Ottawa Kanada. Retrieved from https://kemlu.go.id/ottawa/id/pages/ kewarganegaraan_ganda_terbatas_untuk_anak/ 648/about-service (diakses padā tanggal 06 April 2020)

Khairandy, R. (2007). Pengantar Hukum Perdata
Internasional. Yogyakarta: FH-UII Press

Muhammad, A. (2000). Hukum Perdata Indonesia. Bandung: PT. Citra Aditya Bakti.

Parwitasari, T. A. (2010). Status Kewarganegaraan Anak Yang Terlahir Dari Ibu WNI Dan Ayah WNA Setelah Berlakunya Undang-Undang Nomor 12 Tahun 2006 Tentang Kewarganegaraan Republik Indonesia. Jurnal Ilmiah Sinus, 8 (2), 57-69. Retrieved from https://p3m.sinus.ac.id/jurnal/index.php/ejurnal_SINUS/article/view/20

Rampay, D. L. (2017). Hak Waris Anak dalam Perkawinan Campuran Berdasarkan Undangundang Nomor 12 Tahun 2006 Tentang Kewarganegaraan. MORALITY: Jurnal Ilmu Hukum, 2(2), 107-121. Retrieved from https:// jurnal.upgriplk.ac.id/index.php/morality/article/ view $/ 27$

Rudito, S. (2015). Penerapan Legitime Fortie (Bagian Mutlak) Dalam Pembagian Warisan Menurut Kuh Perdata. Legal Opinion: Jurnal Ilmu Hukum, 3(3). 1-9. Retrieved from https:// www.neliti.com/publications/144989/penerapan -legitime-fortie-bagian-mutlak-dalampembagian-warisan-menurut-kuh-perd

Salim, H. (2011). Pengantar Hukum Perdata Tertulis $(B W)$. Jakarta: Sinar Grafika.

Seto, B. (2001). Dasar- Dasar Hukum Perdata Internasional. Bandung: Citra Aditya Bakti.

Soerjono Soekanto, d. S. (2004). Penelitian Hukum Normatif. Jakarta: Raja Grafindo Persada.

Subekti. (2003). Pokok- Pokok Hukum Perdata. Jakarta: Intermasa.

Utami, P. D. Y., Diantha, I. M. P., \& Sarjana, I. M. (2018). Kedudukan Hukum Grosse Akta Pengakuan Hutang Notariil dalam Pemberian Kredit Perbankan. Acta Comitas: Jurnal Hukum Kenotariatan, 3(1), 201-214. Retrieved from https://doi.org/10.24843/AC.2018.v03.101.p15

Utami, P. D. Y. (2019). Kajian Yuridis Agunan Yang Diambil Alih (Ayda) Oleh Bank. Krettha Dyatmika, 16(2), 69-77. Retrieved from https:// ejournal.undwi.ac.id/index.php/kertadyatmika/ article/download/739/673

Undang-undang Dasar Negara Republik Indonesia Tahun 1945.

Kitab Undang - Undang Hukum Perdata.

Undang- Undang Republik Indonesia Nomor 62 Tahun 1958 tentang Kewarganegaraan Republik Indonesia (Lembaran Negara Republik Indonesia tahun 1958 Nomor 113, Tambahan Lembaran Negara Republik Indonesia Nomor 1647).

Undang- Undang Republik Indonesia Nomor 5 Tahun 1960 tentang Peraturan Dasar Pokok - Pokok Agraria (Lembaran Negara Republik Indonesia tahun 1960 Nomor 104, Tambahan Lembaran 
Negara Republik Indonesia Nomor 2043).

Undang- Undang Republik Indonesia Nomor 1 Tahun 1974 tentang Perkawinan (Lembaran Negara Republik Indonesia tahun 1974 Nomor 1, Tambahan Lembaran Negara Republik Indonesia Nomor 3019).

Undang- Undang Republik Indonesia Nomor 12 Tahun 2006 tentang Kewarganegaraan republik Indonesia (Lembaran Negara Republik Indonesia tahun 2006 Nomor 63, Tambahan Lembaran Negara Republik Indonesia Nomor 4634).

Peraturan Menteri Hukum dan Hal Asasi Manusia Republik Indonesia Nomor 22 Tahun 2012 tentang Kewarganegaraan republik Indonesia (Lembaran Negara Republik Indonesia tahun 2012 Nomor 1370). 